\title{
Homo politicus: a democracia, a evolução moral e o direito
}

\section{Homo politicus: democracy, moral evolution and law}

\author{
Priscila Zilli Serraglio* \\ Neuro José Zambam*
}

\section{Resumo}

O presente trabalho visa examinar as ideias de política e democracia a partir do pensamento de dois grandes autores da Filosofia do Direito, Hannah Arendt e Norberto Bobbio, especificamente por meio da análise do segundo capítulo da obra A condição humana, de Hannah Arendt, e do texto "Democracia representativa e democracia direta", que compõe a obra O futuro da democracia, de Norberto Bobbio, e porque o direito necessita também de uma filosofia de valores. Retrata, portanto, os aspectos público e privado da política como entendida na Antiguidade e compara-a com a ideia de política social contemporânea. Posteriormente, discorre sobre o ideal democrático de Bobbio, apresentando, para isso, os conceitos de democracia representativa e direta. Em seguida, aborda a importância da moral para o direito, pois sem ela o direito perde seu sentido axiológico e, por consequência, o agir político perde a sua qualidade sensível e responsável, tornando-se mecânico e egoísta. Por fim, constrói uma reflexão crítica sobre a convergência do pensamento dos dois autores e a implicação que essa abordagem traz para a vida política e social contemporânea, na medida em que o Estado de Direito exige uma forma de organização social e um sistema jurídico que regulamentem e permitam o exercício da autonomia individual e das liberdades fundamentais. A democracia

\footnotetext{
Advogada. Mestranda bolsista do PPGD da Faculdade Meridional - IMED. Graduada pela Faculdade Meridional - IMED. Porto Alegre - RS. Email: pris_zs@hotmail.com

* Doutorado em Filosofia pela Pontifícia Universidade Católica do Rio Grande do Sul. Pósdoutorando em Filosofia na Universidade do Rio dos Sinos - Unisinos; Doutor em Filosofia pela PUCRS. Professor do Programa de Pós-graduação em Direito da Faculdade Meridional - IMED - Mestrado. Professor do Curso de Direito (graduação e especialização) em Direito da Faculdade Meridional - IMED de Passo Fundo. Membro do Grupo de Trabalho, Ética e cidadania da ANPOF (Associação Nacional dos Programas de Doutor em Filosofia) pela PUCRS. Pesquisador da Faculdade Meridional. Coordenador do Grupo de Pesquisa: Multiculturalismo, minorias, espaço público e sustentabilidade. Porto Alegre - RS.E-mail: neurojose@hotmail.com
} 
é imprescindível para a solução pacífica de conflitos e para que se consiga estabelecer e manter uma convivência coletiva numa época de pluralismo cultural.

Palavras-chave: Política. Democracia. Poder. Pluralismo. Ética.

\section{Abstract}

This article aims to examine the ideas of politics and democracy present through the works of two great juridical philosophy authors', Hannah Arendt and Norberto Bobbio, specifically by analyzing the second chapter of the book "The human condition", from Hannah Arendt, and the text "Representative democracy and direct democracy", from the book "The future of democracy", from Norberto Bobbio, and why the Law also requires a philosophy of values. Describes, therefore, the politics public and private aspects' as understood in the ancient times and compares it with the contemporary social political idea. Later, discusses the democratic ideal of Bobbio, introducing the concepts of representative democracy and direct democracy. Afterwards, argues the importance of morality to the Law, because without it the Law loses its axiological sense, and therefore political action loses its sensible and responsible quality and becomes mechanical and selfish. Finally, develops a critical reflection on the convergence of the thought of these authors and the implication that this approach brings to the contemporary social and political life, to the extent that the rule of law requires a form of social organization and a legal system that regulates and facilitates the exercise of individual autonomy and fundamental freedoms. Democracy is indispensable for the peaceful solution of conflicts and so that it is possible to establish and maintain a collective coexistence in an era of cultural pluralism.

Keywords: Politics. Democracy. Power. Pluralism.

\section{Introdução}

O ser humano, desde que se reconhece como animal racional, diferencia-se dos demais seres vivos pela sua capacidade de raciocínio, que lhe permite, acima de tudo, pensar na sua atuação e nas consequências dela oriundas, agindo de forma direcionada perante o meio que o circunda, modificando-o. O agir humano, nesses termos, 
é composto por duas dimensões: o pensar e o realizar. Esses dois aspectos da ação permeiam toda a vivência em sociedade, seja na esfera individual, seja na coletiva.

É, portanto, por meio da ação que identificamos a nossa condição humana, pois que é ela uma nossas especificidades em relação aos demais seres. É o agir humano que dá sentido à nossa existência, à vida humana e suas interações - passadas, presentes e futuras. Todas as atividades humanas estão condicionadas à necessidade que o indivíduo tem de associar-se com os demais; sem o viver-junto, não há sentido para a ação, pois esta é a externalização do pensar; é por meio dela que o ser humano eterniza-se no tempo; ela cria o artifício humano.

Hannah Arendt, ao tratar da condição humana, refere-se ao agir humano como uma das dimensões da vida ativa (em contraste com a vida contemplativa), através da qual se toma consciência de ser o humano um ser essencialmente político, que necessita da pluralidade de indivíduos para realizar-se, tornando a vivência em sociedade um espaço necessário para a troca de experiências e para a efetivação no tempo histórico.

Nessa linha, assevera sobre as implicações da ação nas esferas pública e priva - como era na Antiguidade e como o é atualmente -, procurando demonstrar a importância da política (da lexis e da práxis) na vida social do homem, e como o poder se relaciona com a política. Procura evidenciar a importância da política na vida humana, pois é a partir e através dela que nos reconhecemos humanos, iguais e diferentes nos limites identitários, e, pretendendo alcançar nossos objetivos, buscamos a coletividade para cooperar nessa cruzada, ainda que o faça imediatamente quanto aos objetivos comuns, e mediatamente quanto aos individuais.

A política, contudo, por se caracterizar como um agir humano, voltada para a prática, é aquilo que fazemos dela, ou seja, pode ser positiva, negativa ou, como mais frequentemente se apresenta, ambivalente. Ela reflete o comportamento humano daquele que a exerce. E é essa ambivalência do animal política que torna o poder 
tão perigoso. O poder está intimamente relacionado às questões que envolvem o problema da discricionariedade, da arbitrariedade, da autoridade, da ordem (bem comum a todas as sociedades) e, necessária e inevitavelmente, também interfere diretamente nos ideais de liberdade e igualdade.

Norberto Bobbio, preocupado com o poder político - pois que este, quando violento, deixa de ser legítimo e político, já que perde a sua capacidade persuasiva (lexis) -, também defende uma sociedade pluralista baseada na divisão do poder político, na sua diluição entre as camadas da sociedade, tornando o corpo político mais homogêneo. O autor defende, por conseguinte, a democracia como sistema de organização social que melhor atende aos anseios e ideais de uma concepção coletiva de vida boa, compreendendo tanto as aspirações particulares como as coletivas. Por isso, procura esclarecer as confusões geradas pelas duas mais populares formas de democracia: a representativa e a direta, distinguindo uma da outra para, por fim, relacioná-las e saudar-nos com a sua teorização de uma democracia ideal.

A democracia, da maneira descrita por Bobbio, é maleável, adaptável às formas de governo que hoje se apresentam pelo globo e conduz ao desenvolvimento social na medida em que permite o dissenso, a convivência das diferenças, possibilitando a abertura da sociedade para o novo, acarretando na constante renovação de valores e no surgimento perene de novas práticas e contribuições ante a sociedade civil.

Este estudo tem como meta uma reflexão crítica sobre o impacto que essa concepção política, isto é, o ideal político e democrático tem na sociedade atualmente. O ser humano, como animal político, necessita da democracia para se realizar, já que esta tem na autonomia um dos seus pilares estruturantes, dependendo, portanto, da liberdade - nas suas mais variadas formas, mas principalmente da liberdade de opinião, que legitima o consenso e, acima de tudo, o dissenso - e da igualdade - principalmente quando traduzida como equidade (igualdade de condições e oportunidades) - para ser-no-mundo. 
Nesse viés, a essencialidade de uma filosofia dos valores resta evidente nos campos da política e do direito, pois é a partir do compromisso moral que o ser humano projeta e direciona seu comportamento e suas ações, responsabilizando-se pelos resultados que produz no meio que habita. ${ }^{1}$ É o consenso sobre mínimos valorativos que permite reconhecer-se e identificar-se nos outros e em si mesmo, deliberando sobre o sentido da vida, da política, do direito, da justiça, da liberdade, da igualdade, da própria existência.

O estudo será dividido em: Introdução; 1) A política como condição humana; 2) O ideal democrático em Bobbio - a necessidade do dissenso; 3) A axiologia como fundamento de um Estado Democrático de Direito; Conclusão. Para tanto, utilizar-se-á do método investigativobibliográfico, realizando-se uma abordagem qualitativa da bibliografia levantada.

\section{A política como condição humana}

Historicamente, o ser humano, a partir do seu reconhecimento como tal, sempre buscou conquistar seu espaço perante os demais, organizando-se em grupos e criando para si uma identidade que o definisse e, então, apesar de suportar deveres em razão dela, protegesse-o em sociedade, vinculando-o a um lugar comum e a indivíduos que o reconheciam como iguais.

A associação é característica fundamental da atividade humana, pois a ação (fazer algo) só tem sentido quando é testemunhada pela presença de outros seres humanos, direta ou indiretamente. O agir humano é especificidade exclusiva do homem e depende da eterna presença do outro, justamente em razão da natureza dialógica da humanidade, constituída por seres de linguagem e comunicação.

Nesse sentido, ver RESWEBER, Jean-Paul. A filosofia dos valores. Tradução de Marina Ramos Themudo. Coimbra: Almedina, 2002. 
Conscientes dessa qualidade, os gregos entendiam o homem como um ser ambivalente, que buscava a realização da vida humana tanto na política (esfera pública) quanto na esfera privada, portanto, concebiam ambos esses aspectos como necessidades humanas vitais, interdependentes, mas completamente distintos e dissociados em seu campo de atuação:

O surgimento da cidade-estado significava que o homem recebera, 'além de sua vida privada, uma espécie de segunda vida, o seu bios politikos. Agora cada cidadão pertence a duas ordens de existência; e há uma grande diferença em sua vida entre aquilo que Ihe é próprio (idion) e o que é comum (koinon)'. (ARENDT, 1981, p. 33).

A política, como forma de aliança dos indivíduos em torno de uma finalidade comum e específica, somente era possível por meio de duas atividades humanas: a práxis (ação) e a lexis (discurso). Tanto uma quanto a outra eram essenciais para a realização da política, que não existia somente com a efetivação de uma delas. Isso porque a persuasão e a retórica desempenhavam um importante papel na busca pela grandeza e pelo poder, objetivos comuns da época. A persuasão, na época grega, intentava o convencimento dos destinatários do discurso.

Por muito tempo, a lexis tomou conta da política e a práxis ficou esquecida. No curso da história, a práxis e a lexis ficaram cada vez mais dependentes, não havendo como se falar hoje em política sem tratar tanto da ação quanto do discurso. Contudo, importante que se diga que a política, tanto a ação quanto a persuasão, não condiz com a violência, pois o fundamento da política é o convencimento a partir da razão, não da coerção (estado pré-político):

[...] forçar alguém mediante violência, ordenar ao invés de persuadir, eram modos pré-políticos de lidar com as pessoas, típicos da vida fora da polis, característicos do lar e da vida em família, na qual o chefe da casa imperava com poderes incontestes e despóticos [...] o domínio absoluto e inconteste e a esfera política propriamente dita eram mutuamente exclusivas. (ARENDT, 1981, p. 36-37). 
É a razão que nos diferencia dos demais animais, é ela que nos faz essencialmente políticos. A política nasce como forma de convívio entre os homens - daí porque Arendt acrescenta à ideia do animal político o aspecto social, advindo dos latinos, que trata da circunscrição dos "aspectos particulares (sociais)" - isto é, o homem político é o homem social, ou vice-versa; o social e o político, quando não são a mesma coisa, são intrínsecos um ao outro.

Essa existência mutualística do social e do político surgiu com a idade moderna, na forma do Estado nacional, portanto, é um fenômeno relativamente novo do ponto de vista histórico, pois, antigamente, a esfera de vida privada correspondia à família, e a esfera de vida pública respeitava a política (polis). O Estado nacional passou a gerir a economia, antes de âmbito exclusivamente familiar, fato que alavancou a passagem dos negócios domésticos para a esfera política e, portanto, social, à medida que a economia doméstica passou a integrar a macroeconomia da sociedade - uma "superfamília" chamada "nação".

A passagem da sociedade - a ascensão da administração caseira, de suas atividades, seus problemas e recursos organizacionais - do sombrio interior do lar para a luz da esfera pública não apenas diluiu a antiga divisão entre o privado e o político, mas também alterou o significado dos dois termos e a sua importância para a vida do indivíduo e do cidadão, ao ponto de torná-los quase irreconhecíveis. (ARENDT, 1981, p. 47).

O privado, hoje, é entendido como sinônimo de intimidade, não de privação como o era antigamente, e isso se deve à ascensão do individualismo. E porque o social e o político se confundem, o privado, não obstante ser oposto a ambos, mantém estreita relação com eles. Isso se deve ao fato de que a ênfase no individualismo despersonificou o Estado (que antes era o governo de um só homem), transformando-o num governo de ninguém, mas que, apesar disso, permaneceu bastante sólido, pois alicerçado na burocracia, permitindo que os indivíduos apoiassem sua soberania e autonomia - e a importante responsabilidade advinda delas - em normas oriundas de um ente despersonificado intitulado 
de "autoridade". Essa delegação de responsabilidade possibilitou aos indivíduos buscar unicamente seus interesses privados, acarretando em um conformismo que excluiu a ação (e as potencialidades de ação) das esferas política e social, posto que conformou o comportamento dos cidadãos às normas de um Estado monopolizador da produção jurídica e aboliu a ação/reação espontâneas.

Considerando esse conformismo, vários autores criticam a idade moderna por conformar e, consequentemente, alienar o ser humano de valores e práticas essenciais a uma convivência pacífica e autossustentável, na medida em que, por padronizar o comportamento, cria uma cultura de massas e impede um olhar atento ao outro em prol de uma atuação mecânica para com o outro. Arendt, nesse sentido, faz uma crítica contundente sobre a necessidade de retomar a ação, a práxis e a lexis, no campo social e político, atentando nas entrelinhas para a urgência de se pensar a economia somente como fator auxiliar da vida política, e não como escopo dela. A ação deve voltar a ser o sentido da política, pois, como animais sociais, a realização das nossas potencialidades somente pode ocorrer no espaço público da coletividade.

A política, portanto, deve ter - e tem - como condição a pluralidade, compreendida como esfera da liberdade - em contraposição, segundo o pensamento grego, à esfera da necessidade visualizada na ordem pública, comum, política ${ }^{2}$ - no sentido de autonomia, através da qual, no espaço público de convívio com os outros, é possível e desejável a realização das capacidades e potencialidades humanas com base no reconhecimento da igualdade (todos são humanos, constituintes de uma mesma categoria e partilham aspectos comuns) e da diferença (apesar das semelhanças, todos apresentam particularidades distintas, que os tornam únicos e, por isso, diferentes).

\footnotetext{
"A igualdade, portanto, longe de ser relacionada com a justiça, como nos tempos modernos, era a própria essência da liberdade; ser livre significava ser isento da desigualdade presente no ato de comandar, e mover-se numa esfera onde não existiam governo nem governados." (ARENDT, 1981, p. 42).
} 
Para Arendt, a política pressupõe um ordenamento baseado na liberdade e na igualdade (formal e material), por meio da qual a práxis e a lexis impõem, num contexto de choque das diferenças humanas gerado pelo estranhamento do outro, a lógica da alteridade baseada na proposição de políticas de reconhecimento no espaço público. Atualmente, esses ideais pensados para o espaço público também constituem o campo de atuação privado, pois a esfera pública comum e a esfera social não são mais conceitos à parte, mas formam uma acepção una, já que cada vez mais Estado e sociedade civil confundemse nos mesmos papéis e no desempenho simultâneo das mais variadas funções.

Os sujeitos são movidos por necessidades, interesses e paixões. A esfera da necessidade e das carências está ligada ao labor e ao trabalho, e a ação está ligada à esfera das coisas comuns da vida política. Para pensar a política, deve-se levar isso em conta, mas também a razão como forma de contenção da violência. A visão da política acusada por Arendt nos remete a refletir sobre a necessidade de uma nova ordem ética, que prime pela ação responsável no mundo, preocupada com a vivência cotidiana a partir do outro, fundada no compromisso com o passado, presente e futuro das gerações. ${ }^{3}$

Essa nova ética deve, considerando que a ação e o discurso inserem o indivíduo no mundo, ser pautada na consciência de ser o humano um sujeito de ação, limitado por sua finitude no tempo e sua incompletude existencial. Justamente porque a ética pressupõe a prática, a habitualidade da ação responsável, devemos acolhê-la como fundamento necessário da política, a qual Arendt trata como momento de maioridade ou maturidade do animal político. Isso porque a práxis política, na complexidade do mundo contemporâneo, não é fácil, exige coragem, estranhamento, tolerância e resiliência.

\footnotetext{
3 "A presença de outros que veem o que vemos e ouvem o que ouvimos garante-nos a realidade do mundo e de nós mesmos [...].". (ARENDT, 1981, p. 60).
} 


\section{O ideal democrático em Bobbio - a necessidade do dissenso}

A realidade imposta por um pluralismo cada vez mais acentuado, oriundo do crescente fenômeno globalizatório, exige a adaptação de todos os artifícios humanos, principalmente do direito, da política e das culturas, para a coexistência e a convivência pacíficas. Contudo, as diferenças acentuam as desigualdades e as necessidades não superadas das sociedades.

A evidência dessas importantes demandas sociais, em contraste com a possibilidade de desenvolvimento e avanço social propiciada pelas trocas de experiência do pluralismo, leva-nos a questionar a melhor forma de organização social para esse atual paradigma. Não obstante os desafios inerentes à complexidade das relações humanas que se acentua com o passar do tempo, ainda o ideal democrático se apresenta como a melhor teoria até agora pensada para lidar com esses dilemas, pois as instituições democráticas, mais do que quaisquer outras, tendem a expor os cidadãos a um grande mosaico de valores culturais, o que nos permite reconhecer o valor de diversas outras culturas e nos ensina a apreciar a diversidade, não somente pelo que ela é, mas também pela melhora da qualidade de vida e aprendizado que oferece.

A democracia, por se caracterizar principalmente pelo direito à livre expressão e à livre associação, direito de representatividade e voto livre, quando realizada na sua plenitude, atinge a todos e integra as manifestações e expressões culturais, explicitando e fomentando as condições de justiça, pois esta só é alcançada quando há o equilíbrio entre a regra da maioria e a proteção dos direitos das minorias, garantindo-se e respeitando-se os direitos fundamentais, base da sociedade brasileira.

Os pilares da democracia são a liberdade e a igualdade; mas é possível pensar a democracia sem a superação das necessidades, se esta é condição para uma verdadeira democracia? As necessidades podem ser superadas? O problema do Estado moderno é que ele ainda se funda em critérios absolutistas, liberais e constitucionalistas, pois 
a coerção (muitas vezes necessária, mas também carente de limites) continua sendo o instrumento da administração, e a arbitrariedade e o nivelamento por classe social permanecem sendo o tino de políticas criminais. A igualdade material sustenta discursos governamentais, carecendo, contudo, de implementação; e os preceitos constitucionais, mesmo sob formas de garantias de direitos, são desvirtuados e interpretados conforme a conveniência da porção hegemônica no poder. Em suma, o Estado moderno não dá conta das demandas sociais; seu ordenamento jurídico não acompanha o desenvolvimento social, portanto, o direito está sempre em retardo.

Esse cenário nos permite refletir sobre o modelo de governança que os cidadãos desejam para fundamentar o sentido das ações políticas e sociais em relação às coisas públicas. Assim, não há como se pensar no direito desvinculado da moral, já que esta permite a produção de princípios e normas imbuídos daqueles valores pelos quais os indivíduos primam e concordam em limitar seus interesses e comportamentos, com o intuito de estabelecer e construir historicamente o seu ideal comum de vida boa e pacífica.

Os impactos ocasionados por esse panorama são inúmeros e profundos, pois atingem todos os setores da sociedade. Dentre eles, um dos mais importantes são as consequências resultantes de uma cultura que assimila e iguala todos, dificultando a adequação a uma cultura da identidade e da diferença. A igualdade é um pilar das sociedades contemporâneas estáveis e democráticas, já que pressupõe o reconhecimento da individualidade de cada um e de todos para a convivência pacífica.

Ante o mundo civilizado, é ela que dá voz aos reclamos dos indivíduos e valida suas ações, pois concede valor jurídico, social e político à humanidade em nós. Apesar disso, a igualdade também agudiza os contrastes multiculturais, sublinhando as diferenças nas diversas camadas comunitárias dos países. Isso porque o reconhecimento do e no outro, ou a sua falta, é o que forma a identidade do indivíduo, que é um ser de linguagem. 
Bobbio, nesse sentido, preza por um ideal democrático pautado na possibilidade do dissenso existente na base das sociedades, pois são as diferenças que provocam a síntese e a sua reciclagem no vivido histórico do tempo, sendo o consenso a legitimação da divergência/dissidência. Nesse prima, o consenso e o respeito ao direito à divergência de opinião formam o ponto de equilíbrio sobre o qual os valores democráticos se apoiam.

Diante do pluralismo que permeia a comunidade global, a tolerância ganhou expressivo destaque como meio para se enfrentar a compatibilidade de verdades contrapostas. Isso porque a convivência pacífica exige o respeito ao outro, e a tolerância se traduz no reconhecimento da irredutibilidade das opiniões, garantia que deriva da liberdade de opinião e de consciência.

Todavia, é preciso destacar que tolerância não significa renunciar à própria verdade ou ser indiferente a qualquer forma de verdade, adotando-se um método de convivência preferível a outra; a tolerância é, substancialmente, um dever ético, um dever de respeitar a liberdade do outro. Em síntese, ela se configura como a condição da viabilidade da política, principalmente numa época em que impera a heterogeneidade de culturas e a problematização dos direitos das minorias, já que visa auxiliar a sociedade a encontrar um modo de vida que permita a todos os pares expressar suas visões. É dizer, a tolerância impõe o igual direito de conviver em meio ao pluralismo, assim como também impõe o direito ao erro.

Sob tal ótica, Bobbio atenta para a necessidade de que se mantenha a dissociação entre os interesses particulares e os interesses comuns, para que não haja a politização integral do homem, resumindo-o a mero cidadão, pois a cultura da diferença é face necessária da qualidade humana, já que sem ela corre-se o risco de tornar o humano objeto do Estado, contribuindo para a sua coisificação e consequente descartabilização, conforme ocorreu com as experiências do totalitarismo e do nazifascismo. 
O cidadão total e o estado total são duas faces da mesma moeda; consideradas uma vez do ponto de vista do povo e outra vez do ponto de vista do príncipe, têm em comum o mesmo princípio: que tudo é política, ou seja, a redução de todos os interesses humanos aos interesses da polis, a politização integral do homem, a resolução do homem no cidadão, a completa eliminação da esfera privada na esfera pública, e assim por diante. (BOBBIO, 1986, p. 43).

É a cultura da diferença e da tolerância com o dissenso que nos permite exercer a cidadania propriamente dita. É através do embate respeitoso de opiniões e experiências que operacionalizamos as teorizações políticas, tornando-as medidas eficazes para a superação gradativa das necessidades e desigualdades. Nesse sentido, a democracia, para Bobbio, é dinâmica e torna-se evolutiva e qualitativa à medida que é continuamente reinventada, estando em um permanente estado de transformação. A teorização de Bobbio sobre a democracia versa basicamente sobre o dilema do distanciamento entre a democracia real e a ideal, que se verifica no plano das "promessas não cumpridas".

Para que se compreenda, então, o verdadeiro sentido da democracia, Bobbio analisa as disparidades entre a democracia representativa e a democracia direta, para então asseverar que a democracia integral, na qual o poder emana do povo, para o povo e pelo povo, só pode ser concebida pela complementaridade entre as duas formas de democracia citadas anteriormente: a representativa e a direta.

[...] os significados históricos de democracia representativa e de democracia direta são tantos e de tal ordem que não se pode pôr os problemas em termos de ou-ou, de escolha forçada entre duas alternativas excludentes, como se existisse apenas uma única democracia representativa possível e apenas uma única democracia direta possível; o problema da passagem de uma a outra somente pode ser posto através de um continuum no qual é difícil dizer onde termina a primeira e onde começa a segunda. (BOBBIO, 1986, p. 52). 
A democracia direta consiste basicamente na participação direta do indivíduo nas deliberações do governo e da sociedade civil que lhe dizem respeito, sem que haja um intermediário para decidir por ele. Sabe-se, contudo, que esse tipo de democracia é inviável ante uma sociedade pluralista e complexa - em termos qualitativos e, principalmente, quantitativos. É também indesejável sob a perspectiva de que pode levar à banalização da política, isto é, das deliberações sobre a res publica, o que levaria à perda de sentido da realização humana e das identidades de cada um.

Diferentemente, a democracia representativa pressupõe que intermediários eleitos pelos cidadãos decidam por eles as questões coletivas comuns a toda a sociedade. Esses representantes, contudo, devem prestar contas de suas ações ante a exigência de transparência e visibilidade, qualidades imprescindíveis para a consolidação de um regime democrático. Assim, intrinsecamente necessário à permanência da democracia é o controle popular da sociedade civil e da opinião pública, ou seja, a democracia representativa, como única condição democrática viável no contexto político-social contemporâneo, precisa ser complementada pela democracia direta, na forma da participação cidadã já referida.

As democracias representativa e direta coexistem, destarte, integrando-se e sendo interdependentes. É essa associação mutualística entre os dois tipos de democracia que constitui uma democracia integral real e se aproxima mais da democracia ideal teorizada pelos estudiosos do tema.

Um sistema democrático caracterizado pela existência de representantes substituíveis é, na medida em que prevê representantes, uma forma de democracia representativa, mas aproxima-se da democracia direta na medida em que admite que estes representantes sejam substituíveis. É um gênero anfíbio, do qual a história, que procede sempre por vias complicadas (ao contrário da natureza que, como se dizia há tempos atrás, segue sempre a via mais curta), nos oferece inúmeros exemplos. Exatamente porque entre 
a forma extrema de democracia representativa e a forma extrema de democracia direta existe um continuum de formas intermediárias, um sistema de democracia integral as pode conter todas, cada uma delas em conformidade com as diversas situações e as diversas exigências, e isto porque são perfeitamente compatíveis entre si posto que apropriadas a diversas situações e a diversas exigências. Isto implica que, de fato, democracia representativa e democracia direta não são dois sistemas alternativos (no sentido de que onde existe uma não pode existir a outra), mas são dois sistemas que se podem integrar reciprocamente. Com uma fórmula sintética, pode-se dizer que num sistema de democracia integral as duas formas de democracia são ambas necessárias mas não são, consideradas em si mesmas, suficientes. (BOBBIO, 1986, p. 52).

Porque a política permeia todos os estratos sociais, ela é condicionada pela sociedade civil, assim como ocorre com a democracia, que tem na coletividade a sua expressão e legitimidade. Por tal motivo, Bobbio assevera que vivemos uma fase de ampliação do processo de democratização, posto que a globalização facilitou o acesso à informação, permitindo ao indivíduo uma maior compreensão do exercício efetivo da participação política - da importância da retomada da ação (práxis e lexis) como animal social e político.

Assistimos a uma inversão do fluxo de poder: antigamente, ele se dava de cima para baixo, com o Estado impondo deveres antes de conceder direitos aos súditos; atualmente, e cada vez mais, há o declínio do Estado e das suas funções, acarretando na diminuição do poder estatal, com o poder partindo de baixo para cima, gerando direitos aos cidadãos e deveres ao Estado, antes de este cobrar obrigações dos sujeitos (antes passivos, agora gradualmente mais ativos).

[...] se hoje se pode falar em processo de democratização, ele consiste não tanto, como erroneamente muitas vezes se diz, na passagem da democracia representativa para a democracia direta quanto na passagem da democracia política em sentido estrito para a democracia social, ou melhor, consiste na extensão do poder [...] da sociedade 
política [...] para o campo da sociedade civil nas suas várias articulações. [...] Deste ponto de vista, creio que se deve falar justamente de uma verdadeira reviravolta no desenvolvimento das instituições democráticas, [...] resumida numa fórmula do seguinte tipo: da democratização do estado à democratização da sociedade. (BOBBIO, 1986, p. 54).

Se direito e poder são dois lados da mesma moeda, posto que a eficácia de ambos depende da realização conjunta dos requisitos da norma jurídica (justiça e validade) e do poder (legitimidade e legalidade), o ponto de equilíbrio entre eles se traduz numa intensa participação popular ativa, somente possível através de um Estado democrático. Com isso, não se almeja um excesso de politização, mas se quer referir à mudança de comportamento moral dos indivíduos para com a esfera pública e as coisas que a partir dela fazem sentido - os bens públicos e coletivos. Almeja-se, ante a complexidade do período contemporâneo, uma atuação humana que tenha como fundamento a responsabilidade, o racionalismo crítico (instrumento elementar na elaboração e interpretação do direito) e a preocupação com a perpetuação dos resultados da ação no tempo.

Bobbio, assim como Arendt, também se preocupa com a banalização da democratização da política na sociedade civil quando a sociedade de massas não dá a devida importância para a participação cidadã, esquecendo-se da sua responsabilidade social, com a justificação do conformismo. A deliberação, por mais dolorida e sofrida que possa ser, é um processo constante e essencial para a prática democrática e, primordialmente, para a política e o social, partes inarredáveis da nossa condição humana. Negar o ativismo enfatizando o individualismo é negar parte da humanidade que nos habita. A retomada de uma ética pautada na atuação responsável para o outro nos obriga a considerar que também detemos certo poder, e que este não está centralizado no Estado, mas distribuído nas diversas camadas sociais, portanto, deve ser reivindicado para uma atuação cidadã consciente. 


\section{A axiologia como fundamento de um Estado Democrático de Direito}

A filosofia dos valores, justamente por ser intrinsecamente fundada no sujeito e este naquela, configura-se de extrema importância para compreender o momento histórico, principalmente o que se vive hoje, em razão de sua grande complexidade, que demanda essa interrelação entre os símbolos, os valores, os significantes, a ética, a moral, o eu, o outro e a coletividade. Ou seja, para efetivamente ser-no-mundo, é necessário que se (re)construa uma crítica reflexiva, com base no reconhecimento dos organismos, que ocorre a partir da estranheza primeira que inicialmente nos impacto no contato com a externalidade do sujeito.

A ideia do valor, principalmente quando se refere aos sujeitos, deve trabalhar a perspectiva da experiência e as várias facetas do sujeito (política, social, individual etc.). Mas isso não significa que a transcendência deve ser rejeitada, porque é ela que nos permite criar ideais simbólicos, individuais e coletivos, referenciais culturais para um diálogo comum, transferindo ao campo do pragmatismo os referenciais, tornando-os significantes à medida que um se confronta com o outro, já que é este que causa a estranheza e, portanto, permite um diálogo de criação e transformação da linguagem.

Quando a experiência individual é compartilhada, tem-se um compromisso de responsabilidade para com o eu e com o outro, pois, à medida que os valores do eu dialogam com os do outro, o eu se constrói e se desconstrói, tornando-se outro, e o outro, na mesma via, torna-se o eu. Ou seja, há uma troca, há uma fruição, pois a subjetividade implica sempre em uma construção e desconstrução das identidades, as quais dependem de valores formados e reciclados constantemente pelo juízo ético, o qual, em razão desse processo que contempla o processo de inadequação do valor, torna possível a realização do saber e do juízo moral:

O juízo moral e o juízo ético diferem, essencialmente, pelos modelos de saber de que se reclamam. O saber 
moral é universal e a priori, fundamentalmente teórico. Tal não é o saber ético, que apela à virtude do razoável mais do que à do racional. [...] Em virtude do seu caráter marginal e paradoxal, o juízo ético dá vida aos valores abstratos da moral, aos valores codificados do direito, aos valores postos em jogo no ritual cultural, aos valores reguladores da deontologia. Submete, em primeiro lugar, a moral definida a priori a uma revisitação, que dá conta de certas particularidades e das situações de exceção. Intervém, depois, para suavizar a rigidez da lei jurídica e colmatar as lacunas, que paralisam a aplicação da justiça. A jurisprudência e o comentário da lei, por esta reivindicada, são o fruto do diálogo hermenêutico entre as exigências éticas e as normas jurídicas. Mesmo em relação ao ritual cultural o juízo ético acusa um recuo. Desenha o lugar neutro, a partir do qual as diferenças culturais são situadas e apreciadas, não só pelas pessoas, que lhe são estranhas, mas também pelas que lhe pertencem. Permite, igualmente, medir com justeza as especificidades linguísticas, religiosas e políticas e, por conseguinte, cultivar este olhar paradoxal, que possibilita a cada um de nós ver-se no exterior de si e perceber, tanto quanto isso é possível, o outro do interior. (RESWEBER, 2002, p. 93-94).

É imperioso observar, por conseguinte, que a civilidade exige o reconhecimento, tornando a opinião significativa e a ação eficaz; caso contrário, a ausência de reconhecimento, ou o reconhecimento deturpado do outro (que também traduz uma desconstrução e uma negação de parte do eu) gera exclusão e pode levar à prática da violência, tanto daquele que produz esse sentimento quanto daquele que sofre.

A relação de dependência e independência do outro, formada por meio da comunicação e da interação, importa, então, na responsabilidade de uma externalização compromissada dos valores através do diálogo, porque é essa interdisciplinaridade das facetas do sujeito que propicia juízos éticos fundados nas exigências e experiências da vida cotidiana, calcando a moral, a qual, por meio da transcendência, gera a valoração e a fixação dos símbolos que constituem a vida individual, social e 
política da humanidade - a justiça, o direito, o bem e mal, a virtude, o belo e o feio, e assim por diante.

[...] não há compromisso sem liberdade interior que permita à pessoa o desprendimento necessário a poder comprometer-se e ser questionada, face aos outros e pelos outros. Tal é a profunda verdade do hegelianismo: o ser-para-si não é para si, a não ser através do outro. A ambivalência exprime-se sob o modo de uma dialética da interioridade e da exterioridade, do cômico, que subsume o individuo concreto, dividido pelas suas contradições. Porém, estas não nos deve ocultar um outro caráter essencial da pessoa, a transcendência, graças à qual eu sou mais do que eu mesmo e posso dispor de mim. Eis por que somos acósmicos, por mais enraizados que estejamos no cosmos; capazes, pelo distanciamento, de conferir um sentido ao determinismo. Distribui-se em três níveis de valores: político, na luta contra a alienação; histórico, na experiência de uma tensão fecunda entre a utopia do progresso e a expectativa escatológica; espiritual, que funda os dois níveis precedentes e define as condições de uma função profética, fonte do otimismo trágico, que inspira toda a atitude ética. [...] A ambivalência, que estabelece a tensão entre a pessoa, o mundo dos objetos e o do encontro; mas que também a estabelece no interior da pessoa, colocando-a entre a fuga e a luta, entre o compromisso e o novo empenho, entre a avareza, crispada pelo ter, e a generosidade, que o sacrifica ao mais-ser. Favorece a eclosão da liberdade e a superação de si, que abre para a experiência da transcendência. (RESWEBER, 2002, p. 77-78).

Esse paradigma permite que se efetive uma coexistência pacífica, equilibrada e harmônica dos cidadãos no mundo, cada vez mais globalizado. A sustentabilidade, portanto, exige a reflexão reconstrutiva de uma axiologia dos valores, que devem ser pautados na subjetividade das experiências humanas entre os indivíduos, com os outros e pelos outros, incluindo-se aqui os demais organismos vivos da Terra.

É essa reflexão preocupada para com o futuro que nos permite uma vida digna, pautada em um olhar que reconhece, aproxima e se 
comunica por meio das particularidades de cada um - as diferenças - e, também, pelo consenso das paridades.

A sustentabilidade se concretiza fluidamente na ação ética do ser humano, que, por meio de juízos de valoração a partir do outro do reconhecimento e da diferença -, busca ser virtuoso no mundo, preocupando-se com a sua identidade que se forma pelo e no mundo, permitindo a prefiguração das várias potencialidades e capacidades de realização humanas.

Essa compreensão converge para um pensamento orgânico que vê que os indivíduos formam, juntamente com o meio em que habitam, um todo interligado, possibilitando uma melhor compreensão dos diversos significados das coisas e das realidades que se impõem. É dizer, tratase de enxergar, vivenciar e externalizar as inúmeras formas de sentir o mundo, já que não existe uma única compreensão das coisas, como propôs a razão instrumentalizada da modernidade.

Assim, essa nova comunidade organicista não confinaria as particularidades, mas permitiria sua fruição nas esferas públicas e privadas. É, portanto, a partir dos contrastes que nos permitem criticar reflexivamente o mundo externo que percebemos uma unicidade das formas de vida e a sua integração.

Nesse sentido, observa-se que o direito e a moral não podem coexistir separadamente, pois a moral só tem pertinência prática quando estabelecida por normas que justificam o seu valor na ordem social; e o direito, por sua vez, só tem legitimidade se servir para garantir e efetivar mínimos valorativos de justiça, liberdade, igualdade e demais virtudes importantes para a vivência pacífica e ordenada de uma sociedade civil.

Há um abismo entre as teorias sobre a democracia e a democracia vivida. Se o cidadão, apenas, se torna sujeito, ao limitar os seus desejos em proveito da vontade geral, como o demonstra Rousseau, ele não deixa intactas as normas, que respeita. Pois, mesmo sem contestar a vontade geral e a sua propriedade, entra em conflito com aquelas. Em suma, tal conflito tem como resultado o transformar as normas em valores. O sujeito encontra diante de si fronteiras, mas, ao 
desloca-las para as inverter em limites, converte-as em referenciais. [...] Estas diferentes figurações são os perfis do sujeito ético, que só passa a existir quando inscrito no horizonte do mundo em comum. De representações, os valores tornam-se, então, fins. (RESWEBER, 2002, p. 4344)

O Estado Democrático de Direito, portanto, depende de uma filosofia dos valores para servir aos fins humanos para os quais foi criado, permitindo à humanidade a criação de redes interacionais e a facilidade de comunicação e diálogo, incentivando um amadurecimento das relações humanas (por meio, principalmente, desse progresso moral) e o consequente desenvolvimento equilibrado dos artifícios humanos que compõem a civilidade - destacando-se o agir político como condição para a cooperação e resistência a uma ciência mecanicista que tudo limita e conforma, sem possibilitar a dinamicidade da vida social e aquilo que esta engloba.

\section{Conclusão}

Atualmente, as fontes do direito não advêm unicamente do Estado. Este, quando passou a gerir a política e a economia, tornandoas funções comuns ao monopólio do poder estatal, permitiu que, aos poucos - conforme os indivíduos fossem tomando consciência de que é a soberania popular que cria e sustenta o Estado como artifício humano, e não o oposto -, outras instituições começassem a influenciar a produção normativa, a ponto de tal influência passar a ser tão intensa que essas instituições vieram a se configurar como fontes criadoras de direito, para além do Estado.

A ênfase na autonomia do indivíduo corresponde ao momento em que o ser humano perde a característica de objeto do poder, de sujeito passivo, e passa a ser sujeito ativo do direito e da política. Essa nova configuração da cidadania, integrada ao contexto democrático, confere titularidade de poder ao povo em sua totalidade, não só ao indivíduo singular, reconhecido como sujeito de direitos. 
Esse novo cenário integra como novos agentes as ONGs, as empresas transnacionais, os blocos econômicos e culturais, os sindicatos, os organismos internacionais como o FMI, a ONU, e vários outros atores que desempenham um papel decisivo no contexto global de interação e cooperação para a manutenção do vínculo antropológico comum dos seres humanos como espécie que pretende perpetuar a sua existência de forma pacífica, necessitando, para tanto, que se pense em um desenvolvimento pautado na sustentabilidade, somente possível num espaço no qual se cultivem princípios democráticos, isto é, no qual impere a liberdade como forma de realização das potencialidades humanas, apenas praticável em um ambiente que esteja de acordo com a autonomia individual, a qual é condição para que a responsabilidade permeie a ação e o discurso humanos, retomando-se, assim, o verdadeiro sentido da política.

Vivemos, hoje, um período histórico, marcado pela ampliação da liberdade e pela consequente (re)democratização da sociedade civil, que, animada pelas redes formadas numa era de intensificação da globalização e da expansão da informação e de seu acesso, volta um olhar mais atento para a res publica e passa a ocupar e a reivindicar os espaços públicos como lugares de diálogo, de reconhecimento, de construção e reconstrução de valores, de um agir político até então esquecido, mas latente.

O processo de conscientização dos seres humanos quanto à força popular do agir político - aqui entendido como a participação na vida da polis (esfera de deliberação das coisas públicas/sociais) - vem tomando forma e se fortalecendo à medida que a autonomia - como a capacidade de gerir os próprios negócios e decidir sobre a própria vida, realizando as potencialidades humanas - passa a ter uma maior importância na vida dos indivíduos, somente possível ante os princípios democráticos e os valores da liberdade e da igualdade.

Nesse sentido, a cidadania ganha novo e maior peso quando se constata que o artifício da civilidade exige-a como condição para a identidade jurídico-política, dando voz aos anseios e reivindicações 
e sentido aos comportamentos dos indivíduos em sociedade. Por tal motivo, é fato que a cidadania possui tanto um status legal, que se traduz num conjunto de direitos, quanto um status moral, do qual decorrem, em contrapartida, as responsabilidades advindas dos comportamentos de cada um.

Entretanto, a cidadania só se efetiva como valor num contexto de igualdade de oportunidades, no qual todos os cidadãos possam compartilhar do sentimento de justiça e dos interesses pelas tarefas coletivas. Nessa lógica, a cidadania, como princípio de realização e (re) afirmação das identidades, deve ter como norte um pluralismo atento à complexidade das relações humanas e ao respeito para com o outro, vendo nele a possibilidade de se (re)descobrir e se (re)inventar.

O reconhecimento das múltiplas identidades culturais deve, portanto, embasar nosso ideal de moral e de política da sociedade que queremos construir e transferir às gerações futuras, pautando a educação numa ética voltada para o viver-junto, para o ser-no-mundo, em que se busca uma aproximação dos valores metafísicos e, portanto, da racionalidade, com a sensibilidade humana a partir da experiência cotidiana e histórica.

É esse o panorama que nos permite verificar uma ética intercultural que educa os cidadãos para os valores importantes de uma cidadania responsável e propicia um universalismo dialógico à medida que se aceita a finitude e as insuficiências humanas e se percebe aí a capacidade de renovação da humanidade em si e no outro por meio da comunicação - da possibilidade de um consenso e da validade e legitimidade do dissenso (respeitoso).

O desafio democrático é primordialmente moral e ético; a regulação pela política e pelo direito é uma formalidade necessária para a consolidação e internalização dos valores abraçados e que se tornam caros nas sociedades plurais, tais como aqueles que definem o sentido da vida (boa), da felicidade, da justiça, da organização social, e para que a violação de uma dessas garantias possa ser desincentivada, impedida e/ou reparada pelos polos de poder distribuídos numa sociedade 
democrática, por meio da sua jurisdicionalização. De qualquer forma, uma cidadania tal exige um aparato estatal que assuma como parâmetro um liberalismo abrangente e mantenha espaços de diálogo e fomento à convivência pacífica de uma sociedade complexa, aberta e altamente porosa.

O convívio e o agrupamento fazem parte da natureza do homem, que precisa dos outros para formar sua identidade e dar sentido ao seu eu-no-mundo, complemento do eu moral, que forma a identidade pessoal por meio da autenticidade, das particularidades próprias de cada um. Nesse aspecto, o diálogo se projeta como uma exigência para a perpetuação das tradições de sentido, especialmente o de justiça e o da vida, impulsionando o amadurecimento moral da humanidade e o aperfeiçoamento dos artifícios criados para melhorar e facilitar o convívio humano e a troca de experiências no meio em que se vive. A promessa moral do Estado Democrático de Direito depende dessas virtudes deliberativas.

\section{Referências}

ARENDT, H. A condição humana. Rio de Janeiro: Forense-Universitária, 1981.

BOBBIO, Norberto. A era dos direitos. Rio de Janeiro: Elsevier, 2004.

BOBBIO, Norberto. O futuro da democracia: uma defesa das regras do jogo. Rio de Janeiro: Paz e Terra, 1986.

CORTINA, Adela. Cidadãos do mundo: para uma teoria da cidadania. Tradução de Silvana Corbucci Leite. São Paulo: Loyola, 2005. p. 139210.

RESWEBER, Jean-Paul. A filosofia dos valores. Tradução de Marina Ramos Themudo. Coimbra: Almedina, 2002.

Recebido em: 17/10/2014

Aprovado em: 04/02/2015 